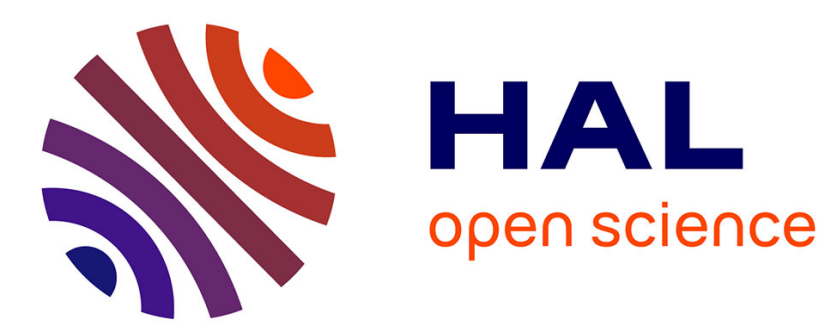

\title{
HIGH PRECISION BAND CALCULATION OF Nb3Sn IN THE A-15 CUBIC PHASE
}

\author{
A. van Kessel, H. Myron, F. Mueller
}

\section{To cite this version:}

A. van Kessel, H. Myron, F. Mueller. HIGH PRECISION BAND CALCULATION OF Nb3Sn IN THE A-15 CUBIC PHASE. Journal de Physique Colloques, 1978, 39 (C6), pp.C6-414-C6-415. 10.1051/jphyscol:19786186 . jpa-00217601

\section{HAL Id: jpa-00217601 https://hal.science/jpa-00217601}

Submitted on 1 Jan 1978

HAL is a multi-disciplinary open access archive for the deposit and dissemination of scientific research documents, whether they are published or not. The documents may come from teaching and research institutions in France or abroad, or from public or private research centers.
L'archive ouverte pluridisciplinaire HAL, est destinée au dépôt et à la diffusion de documents scientifiques de niveau recherche, publiés ou non, émanant des établissements d'enseignement et de recherche français ou étrangers, des laboratoires publics ou privés. 


\title{
HIGH PRECISION BAND CALCULATION OF $\mathrm{Nb}_{3} \mathrm{~S}_{n}$ IN THE A-15 CUBIC PHASE
}

\author{
A.T. Van Kesse1, H.W. Myron and F.M. Mueller \\ Physics Laboratory and Research Institute for Materials, University of Nijmegen, \\ Toernooiveld, Nijmegen, The Nethertands.
}

\begin{abstract}
Résumé.- Un nouveau calcul de haute precision a été effectué pour les bandes de $\mathrm{Nb}_{3} \mathrm{Sn}$ au moyen de la méthode APW; des corrections au potentiel y sont incluses et à l'intérieur et à 1 'extérieur de la sphère mufinin-tin Les résultats (surface de Fermi, densité d'états, etc..) sont en bon accord avec huit expêriences différentes. Nous en concluons que notre modèle est d'une bonne précision.
\end{abstract}

\begin{abstract}
A new precision band calculation has been undertaken for $\mathrm{Nb} 3 \mathrm{Sn}$ using the APW method with potential corrections included inside and outside the muffin-tin spheres. The results (Fermi surface, density of states, etc..) show good agreement with eight experiments. It is concluded that the band model is highly accurate.
\end{abstract}

Interest in the A-15 high temperature superconductor $\mathrm{Nb}_{3} \mathrm{Sn}$ began with its discovery over 20 years ago $/ 1 /$, yet interest remains high today. Primarily this recent interest focused on a number of anomalous normal state properties $/ 2 /$, those measured above the superconducting transition temperature. Theoretical models have been used to correlate or make these anomalous properties understandable. Many of these have focused on the explicit point group symmetry of selected points in the Brillouin zone; others have invoked the use of tight-binding schemes with a variety of couplings within or between the dominant d-electron $\mathrm{Mb}$-chains. In this paper we treat the electronic structure globally /3/. Our technique and methodology is similar to the well known APW work of Mattheiss $/ 4 /$. We differ in only two ways : i) the inclusion of non-spherical potential corrections within the muffin-tin spheres; $i i)$ the use of the APW secular matrix itself as an "interpolation scheme", without reliance on an intermediate S1ater-Koster like fit, when extreme precision was desired. All elements were treated so as to maintain an overall precision of better than $3 \mathrm{mRy}$. The details will be published elsewhere /3/. Both Mattheiss and ourselves fit the XPS spectra /5/ equally w 1 .

In Figure 1 we show the band structure on a fine scale. Making a microscopic comparison with Mattheiss' Figure $6(\mathrm{~d})$, one can see that there are major changes. The bands associated with $\Gamma_{12}$ have become flatter and an entire set of bands near $M$ has "popped up" through the Fermi level $\left(E_{F}\right)$.

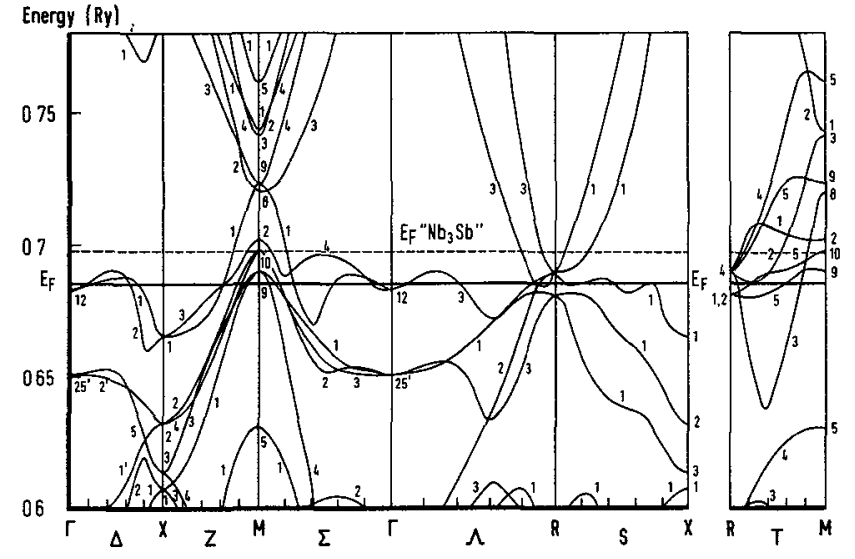

Fig. 1 : The band structure of $\mathrm{Nb}_{3} \mathrm{Sn}$ near $\mathrm{E}_{\mathrm{F}}$.

Raising $E_{F}$ by 2 electrons/unit cell, we find intersections which agree well with the $\mathrm{Nb}_{3} \mathrm{Sb}$ dHvA structure of Reference /6/. Since most of the electrons near $\mathrm{E}_{\mathrm{F}}$ in both $\mathrm{Nb}_{3} \mathrm{Sn}$ and $\mathrm{Nb}_{3} \mathrm{Sb}$ are primarily due to $\mathrm{Nb}$ d-electrons such "rigid band" behavior is not really surprizing. Nevertheless, a careful examination shows that a rigid band model has even quantitative accuracy.

In Figure 2 we show the density of states, $\mathrm{N}(\mathrm{E})$, on a similar scale as Figure 1. The values shown were linear1y. interpolated between a sequence of values of energy spaced $1.25 \mathrm{mRy}$ apart. A1though it is always possible that fine structure in $\mathrm{N}(\mathrm{E})$ of $\mathrm{A}-15$ materials exists "between" the grid-we häve chosen, we believe that the probability for such fine structure falling just at $E_{F}$ is unilkely. Thus in our results the peaks in $\mathrm{N}(\mathrm{E})$ are narrow compared with that for a typical transition metal. 


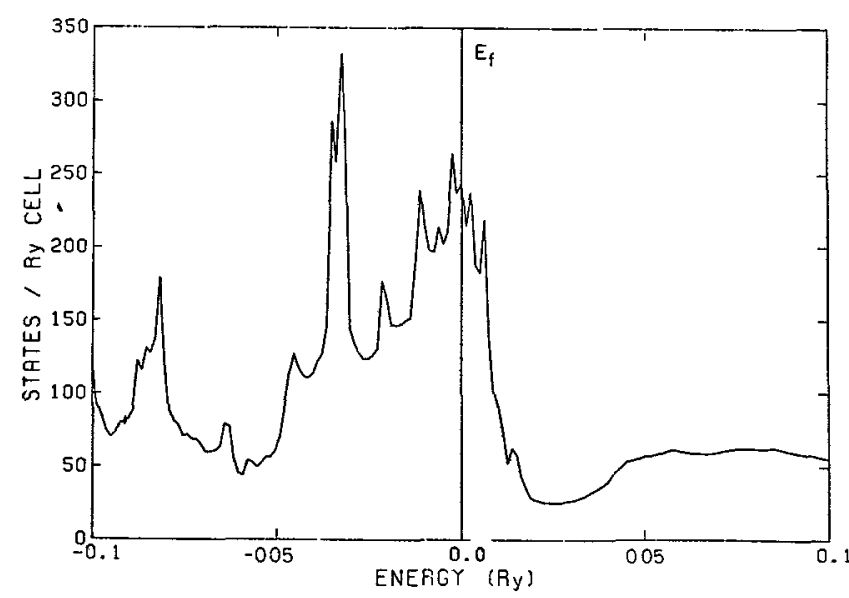

Fig. 2 : The density of states near $E_{F}$.

The $\Gamma_{12}$ levels in Figure 3 are about $20 \mathrm{mRy}$ wide compared with 150 mRy for a typical transition metal, but our narrow peaks are vast1y broader than a typical thermal energy $k_{B} T$ - about $2 \mathrm{mRy}$ for $300 \mathrm{~K}$. We find no evidence to support a Jahn-Teller effect.

Using the value of $\mathrm{N}\left(\mathrm{E}_{\mathrm{F}}\right)$ we find consistent behavior with both the electronic part of the specific heat $/ 7 /$ and the temperature dependence of the susceptibility $/ 8 /$, details will be published elsewhere $/ 3 /$.

In figure 3 we present the derived Fermi surface of $\mathrm{Nb}_{3} \mathrm{Sn}$. The results are rather complicated reflecting, the eight atom/unit cell geometry in real space. Yet two simplifying features emerge: i) the set of light massed osculatted ellipsoids centered at $\mathrm{M}$; $i i)$ the flat box-like structures centered at $\Gamma$. Recently dHvA /9/ oscillations have been seen consistent with the $M$ centered structure. Positron annihilation measurements $/ 10 /$ in the (100) direction of isoelectronic $\mathrm{V}_{3} \mathrm{Si}$ show structure at $0.185,0.635$ and $0.844 \pi / a$ units.

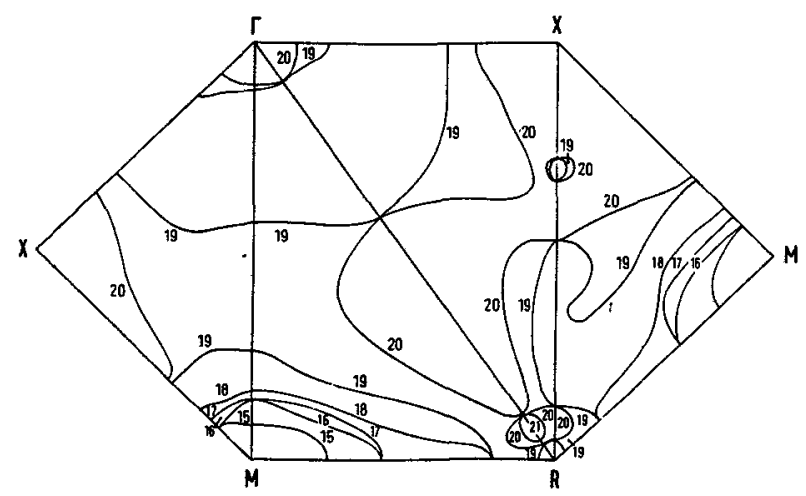

Fig. 3 : The Fermi surface of $\mathrm{Nb}_{3} \mathrm{Sn}$.
The calculated intersection of the Fermi surface "flat" sheets along $\Gamma$ to $X$ are 0.15 and $0.64 \pi / a$ units, in good agreement with the first two pieces of structure. The twentieth band near $X$ along with the 20 th band surrounding the $X-R \cdot 1 i n e$ is a possible candidate for the third structure but this identification is tentative. We have also assumed a microscopic similarity between the electronic structure of $\mathrm{Nb}_{3} \mathrm{Sn}$ and $\mathrm{V}_{3} \mathrm{Si}$ in the above.

In summary the electronic band structure we have calculated fits globally as seen for the comparison with the XPS work $/ 5 /$, fits in zeroth derivative of $N(E)$ at $E_{F} / 7 /$, fits in the first derivative as seen from the temperature dependence of the susceptibility $/ 8 /$, fits the Hall constant $111 /$, fits the Junod value of the electronic specific heat $17 /$, fits the dHvA data of $\mathrm{Nb}_{3} \mathrm{Sb}$ in the rigid band sense $/ 6 /$ as well as $\mathrm{Nb}_{3} \mathrm{Sn} / 9 /$, and fits some of the $\beta^{+} \mathrm{V}_{3} \mathrm{Si}$ data $/ 10 /$. We know of no previous A-15 calculation which has simultaneously fit so many experiments.

This work was performed as part of the research program of the "Stichting voor Fundamentel Onderzoek der Materie" (FOM) with financial support from the "Nederlandse Organisatie voor Zuiver Wetenschappelijk Onderzoek" (ZWO).

\section{$\underline{\text { References }}$}

11/ Hardy, G.F. and Hulm, J.K., Phys.Rev. 93 (1954) 1004. Geller,S. and Matthias, B.T., J. Am.Chem. Soc. 77 (1955) 1502.

12/ Weger,M. and Goldberg,J.B., Solid State Physics Vo1. 28 (Academic Press,N.Y.) (1973); 'Lestardi,L.R., Physical Accoustics Vol. 10 (Academic Press, N.Y.)(1973), Vo1. 13 (1977).

13/ Van Kessel, A.T., Myron, H.W. and Mueller,F.M. (to be published).

/4/ Mattheiss,L.F., Phys.Rev.B 12(1975) 2161.

/5/ Höchst,H., Hüfner, S. and Goldman, A., Solid State Commun.19 (1976) 899.

/6/ Arko,A.J., Fisk,Z. and Mueller,F.M., Phys.Rev. B 16 (1977) 1387.

/7/ Junod,A. (unpublished); Fradin,F.Y., Knapp,G.S . Bader, S.D., Cinader, G. and Kimbal1,C.W., (to be published).

/8/ Rehwald,W., Rayl,M., Cohen,R.W. and Cody,E.D. Phys. Rev.B 6 (1972) 363.

19/ Arko,A.J. et al., (to be published).

$/ 10 /$ Samoilov, S. and Weger,M., Solid State Commun. 24 (1977) 821 .

/11/ Cody,G.D., (private communication). 